\title{
Perlindungan Hukum Terhadap Kedaulatan Negara Dari Ancaman Proxy War
}

\author{
Igam Arya Wada \\ Magister Ilmu Hukum Fakultas Hukum Universitas Jember \\ Email : igamaryawada@gmail.com
}

\begin{abstract}
Proxy war is a form of non-military war by using a non-state actor instead of a particular party, to avoid a direct dispute. One of the non-state actors who are vulnerable to use foreign parties to launch proxy war in Indonesia is the existence of radical organizations either with radical action or radical thinking. In addition, the spread of provocative information and hoax can easily spread through the mass media and social media today, causing problems to the integrity of the Unitary Republic of Indonesia. So far Indonesia has no laws that can counter the nirmiliter threat such as proxy war so that Indonesia is in need of a law that can be used as a preventive effort to protect the state sovereignty against the existence of proxy war in Indonesia. In addition, the public understanding of Pancasila ideology as a way of life should be a necessity in the life of nation and state is still low, so it will be difficult to ward off another ideologies such as radicalism that developed in Indonesia.
\end{abstract}

Keywords: Proxy War, State Sovereignty, Radicalism, Defense and Security

\begin{abstract}
Abstrak
Proxy war adalah suatu bentuk perang non-militer dengan menggunakan actor non-state sebagai pengganti dari pihak tertentu, untuk menghindari perselisihan secara langsung. Salah satu actor non-state yang rentan digunakan pihak asing untuk melancarkan proxy war di Indonesia yaitu adanya ormas Radikal baik dengan aksi radikal ataupun pemikiran radikalnya. Selain itu penyebaran informasi provokatif dan hoax dengan mudah dapat menyebar melalui media massa serta media sosial saat ini sehingga menyebabkan permasalahan tersendiri terhadap keutuhan kedaulatan NKRI. Selama ini Indonesia tidak memiliki undang-undang khusus yang dapat menangkal ancaman nirmiliter proxy war sehingga Indonesia sangat memerlukan adanya undang-undang yang dapat dijadikan sebagai upaya preventif untuk melindungi kedaulatan negara terhadap adanya proxy war di Indonesia. Selain itu pemahaman masyarakat akan ideologi Pancasila sebagai way of life yang seharusnya menjadi sebuah kebutuhan dalam kehidupan berbangsa dan bernegara
\end{abstract}


Fairness and Justice: Jurnal Ilmiah Ilmu Hukum

p-ISSN: 1858-0106 e-ISSN: 2502-3926

Volume 17 Nomor 1 Mei 2019, Hlm 36-56

http://jurnal.unmuhjember.ac.id/index.php/FAJ

masih rendah, sehingga akan susah menangkal ideologi lain seperti radikalisme yang berkembang di Indonesia.

Kata Kunci: Proxy War, Kedaulatan Negara, Radikalisme, Pertahanan dan Keamanan

\section{Pendahuluan}

Setiap negara di dunia memiliki segi historisnya masing-masing seperti Indonesia yang menjadi negara merdeka pada tanggal 17 Agustus 1945 tentunya dengan sejarah panjang yang terjadi sebelumnya. ${ }^{1}$ Proxy war adalah suatu bentuk peperangan yang terjadi akibat dari adanya perang dingin yang tidak pernah selesai sehingga proxy war dapat dikatakan juga sebagai ancaman nirmiliter terhadap kedaulatan Negara. Proxy war dilakukan dengan menggunakan actor non-state sebagai pengganti dari pihak asing, untuk menghindari perselisihan secara langsung sekaligus terhindar dari beban moral politik international. ${ }^{2}$ Salah satu actor non-state yang rentan ${ }^{3}$ dimanfaatkan dan digunakan sebagai pengganti dari pihak asing yang dimaksudkan yaitu dengan adanya Organisasi Masyarakat (Ormas) yang memiliki paham Radikal sehingga membahayakan kedaulatan Negara Kesatuan Republik Indonesia (NKRI). ${ }^{4}$

Beberapa ormas Radikal yang dapat dijadikan sorotan terhadap kerentanan tersebut dalam melancarkan proxy war di Indonesia adalah Front Pembela Islam (FPI) dan Hizbut Tahrir Indonesia (HTI). Kedua ormas ini merupakan actor Radikalisme yang memiliki pandangan

1 Dadan Wildan, M Hum \& Staf Khusus Menteri Sekretaris Negara RI, "Membuka Catatan Sejarah: Detik-Detik Proklamasi, 17 Agustus 1945” (2014) 17 Ministry State Secretary Republik Indonesia Jkt, Hlm 1.

2 Pengertian tentang proxy war tersebut merupakan kajian yang terdapat dalam buku Yehu Wangsajaya, Meningkatkan Kewaspadaan Nasional Terhadap Proxy War, 1 (Jakarta: RajaGrafindo Persada, 2016) Hlm 18. lihat juga dalam buku Andrew Mumford, Proxy Warfare (Cambridge: Polity Press, 2013) Hlm 1.

3 Penulis menggunakan kata "rentan" sebagai kata bantu karena pengertian kata "rentan" diartikan menghasilkan akibat yang tidak dapat diduga. Lihat dalam "Arti kata rentan - Kamus Besar Bahasa Indonesia (KBBI) Online", online: <http://kbbi.web.id/rentan>.

4 Yehu Wangsajaya, supra note 3 Hlm 18. 
Fairness and Justice: Jurnal Ilmiah Ilmu Hukum

p-ISSN: 1858-0106 e-ISSN: 2502-3926

Volume 17 Nomor 1 Mei 2019, Hlm 36-56

http://jurnal.unmuhjember.ac.id/index.php/FAJ

Radikalisasi berbeda di Indonesia. ${ }^{5}$ Selain itu kedudukan dari adanya kedua ormas Radikal tersebut berada di pusat pemerintahan negara, ${ }^{6}$ dan tidak memadainya ketentuan mengenai sanksi dalam Undang-Undang Nomor 17 Tahun 2013 Tentang Organisasi Kemasyarakatan (UU No 17 Tahun 2013) dapat dimanfaatkan oleh pihak asing untuk melancarkan proxy war di Indonesia.

Sumber kerentanan lain terdapat di dalam fungsi media massa dan juga media sosial yang tidak seimbang dengan peraturan perundangundangan yang ada. ${ }^{7}$ Kemudian dengan tidak adanya Peraturan perundang-undangan khusus yang mengatur sebagai antisipasi ancaman proxy war akan melemahkan kedaulatan NKRI di masa yang akan datang. Selain itu, bangsa Indonesia juga memerlukan adanya suatu lembaga khusus yang dapat membantu masyarakat dalam mengimplementasikan nilai-nilai dalam ideologi Pancasila karena saat ini bangsa Indonesia kurang memahami Ideologi Pancasila yang merupakan kebutuhan untuk diterapkan dalam kehidupan sehari-hari. ${ }^{8}$ Maka dengan demikian akan menjadi permasalahan tersendiri terhadap pembentukan karakter bangsa Indonesia di era-globalisasi dengan masuknya ideologi lain seperti Radikalisasi saat ini.

\section{Metode Penelitian}

\footnotetext{
5 Ninin Prima Damayanti et al, "Radikalisme Agama Sebagai Salah satu Bentuk Perilaku Menyimpang: Studi Kasus Front Pembela Islam" (2012) 3:1 J Kriminol Indones, online: <http://journal.ui.ac.id/jki/article/view/1119> Hlm 3.

6 Al-Zastrouw Ng, Gerakan Islam Simbolik: Politik Kepentingan FPI, 1st ed (Yogyakarta: LKIS Pelangi Aksara, 2006) Hlm 89.

$7 \quad$ Yehu Wangsajaya, supra note 3 Hlm 63.

8 Dominikus Rato, "Korelasi Pancasila, Proklamasi, dan Pembukaan Konstitusi" dalam Pancasila Sebagai Realitas Percik Pemikir Tentang Pancasila Isu-Isu Kontemporer Indones, 1st ed (Yogyakarta: Pustaka Pelajar, 2016) 412 Hlm 26.
} 
Fairness and Justice: Jurnal Ilmiah Ilmu Hukum

p-ISSN: 1858-0106 e-ISSN: 2502-3926

Volume 17 Nomor 1 Mei 2019, Hlm 36-56

http://jurnal.unmuhjember.ac.id/index.php/FAJ

Untuk kebenaran atas suatu karya ilmiah maka di dalam penelitian harus menggunakan sebuah metodologi yang tepat, karena hal tersebut merupakan pedoman yang menentukan akan kualitas hasil yang didapatkan atas suatu penelitian. Berdasar atas pendapat di atas, penelitian tentang perlindungan hukum keterwakilan perempuan dalam pemilihan umum legislatif dalam tata hukum di Indonesia merupakan penelitian yuridis normatif. Penelitian yuridis normatif merupakan penelitian kepustakaan yang menggunakan sumber bahan hukum kepustakaan. ${ }^{9}$

\section{Hasil dan Pembahasan}

\subsection{Bentuk-Bentuk Ancaman Proxy War Terhadap Kedaulatan Negara} Kesatuan Republik Indonesia (NKRI)

\subsubsection{Ormas Radikal Sebagai Bentuk Actor Non-State Dalam Proxy War}

Indonesia memiliki potensi untuk dimanfaatkan oleh pihak asing dalam melancarkan strategi proxy war. Hal tersebut dapat dibuktikan dari adanya actor non-state berupa ormas Radikal yang rentan dimanfaatkan sebagai pengganti dari adanya kepentingan pihak asing, dimana ormas Radikal ini selalu menggunakan nama agama Islam pada setiap aksinya dalam masyarakat Indonesia yang majemuk. ${ }^{10}$ Penulis akan menjelaskan adanya tiga sumber kerentanan dimana pada akhirnya ormas Radikal tersebut rentan dimanfaatkan sebagai actor non-state untuk menggantikan kepentingan pihak asing dalam melancarkan proxy war di Indonesia,

\footnotetext{
${ }^{9}$ Sidi Alkahfi Setiawan. 2013. Perlindungan Hukum Pekerja Pemegang Saham Di PT Bank Central Asia Tbk. Fakultas Hukum Universitas Jember. Jember. hlm. 18

10 Kelompok Islam Radikal di Indonesia mempunyai hubungan erat dengan ideologi Islam Radikal yang berkembang di banyak negara seperti Kawasan Teluk dan Asia Selatan. Bahkan jaringan dan pola gerakan Islam Radikal di Indonesia juga berkaitan dengan gerakan perlawanan kelompok Islam di Filipina, Malaysia, dan Thailand Al Khanif, "Pancasila Dalam Pusaran Islam Transnasional" in Pancasila Dalam Pusaran Globalisasi, 1st ed (Yogyakarta: LKis, 2017) Hlm 120.
} 
Fairness and Justice: Jurnal Ilmiah Ilmu Hukum

p-ISSN: 1858-0106 e-ISSN: 2502-3926

Volume 17 Nomor 1 Mei 2019, Hlm 36-56

http://jurnal.unmuhjember.ac.id/index.php/FAJ

Pertama, FPI dan HTI merupakan ormas yang memiliki pandangan radikalisasi berbeda. Jika melihat FPI secara lebih dalam lagi, akan diketahui bahwa orientasi ormas Radikal ini bukanlah pada format dan bentuk kelembagaan sesuai dengan aturan dalam UU No 17 Tahun 2013.11 FPI sejak awal memang berorientasi pada gerakan untuk menumpas kemaksiatan dengan cara-cara kekerasan artinya radikalisasi yang dilakukan FPI yaitu dengan aksi-aksi kekerasan.12 Selain itu, sebagai ormas yang berorientasi pada gerakan agama maka gerak dan langkah ormas ini berada dibawah kendali langsung pemimpinnya. ${ }^{13}$ Sedangkan Radikalisasi yang dilakukan HTI merupakan radikalisai yang bergerak secara diam-diam dengan cara dakwah khilafah islamiyah dan menolak Pancasila serta UUD NRI 1945, menyalahkan hukum yang digunakan di Indonesia dan ingin menggantinya dengan sistem hukum yang dianggapnya lebih baik yaitu Sistem Hukum Islam dan HTI berpandangan bahwa Pancasila bukanlah agama yang harus ditaati. ${ }^{14}$ Sehingga apa yang dilakukan FPI dan HTI akan sangat rentan dimanfaatkan oleh pihak asing untuk melancarkan proxy war di Indonesia. ${ }^{15}$

Kedua, penulis melihat kerentanan lain yang dapat dimanfaatkan oleh pihak asing yaitu karena letak kedudukan FPI dan HTI yang berada di pusat pemerintahan negara. ${ }^{16}$ Kerentanan tersebut terlihat pada kasus

\footnotetext{
11 Lihat Pasal 12 dan 16 UU No 17 Tahun 2013

12 Al-Zastrouw Ng, supra note 7 Hlm 93.

13 Ibid Hlm 95.

14 Al Khanif, "Pancasila dan Agama: Teman atau Lawan?" in Pancasila Sebagai Realitas Percik Pemikiran Tentang Pancasila Isu-Isu Kontemporer Indonesia, 1st ed (Yogyakarta: Pustaka Pelajar, 2016) 412 Hlm 172.

15 Abdurachman Wahid berpendapat bahwa Gerakan Islam Transnasional dan Kelompokkelompok Islam radikal garis keras telah menuduh Pancasila sebagai penyebab degradasi moral dan keterpurukan bangsa Indonesia. Selengkapnya lihat dalam Abdurrachman Wahid, Ilusi Negara Islam : Ekspansi Gerakan Islam Transnasional di Indonesia, 1st ed (Jakarta: The Wahid Institute, 2009) Hlm 33-36.

16 FPI secara resmi berdiri pada 17 Agustus 1998, bertepatan dengan 24 Rabiuts Tsani 1419 $\mathrm{H}$, di pondok pesantren Al-Umm, kampong Utan, Ciputat, Jakarta Selatan. Lihat selengkapnya
} 
Fairness and Justice: Jurnal Ilmiah Ilmu Hukum

p-ISSN: 1858-0106 e-ISSN: 2502-3926

Volume 17 Nomor 1 Mei 2019, Hlm 36-56

http://jurnal.unmuhjember.ac.id/index.php/FAJ

yang menjadi sorotan akhir-akhir ini yaitu FPI ikut serta dalam demonstrasi besar-besaran dikenal dengan Aksi Bela Islam meskipun motif keadaan tersebut adalah politik pilkada. ${ }^{17}$ Sedangkan HTI yang merupakan ormas Islam paling fokus memperjuangkan terwujudnya Negara Khilafah Islamiyah memiliki beberapa strategi yaitu, tahapan yang paling penting dalam semua proses yang dijalankan HTI yaitu pengambilalihan kekuasaan negara. ${ }^{18} \mathrm{Hal}$ inilah yang juga menjadi kerentanan bagi ormas Radikal seperti FPI dan HTI untuk dimanfaatkan pihak asing sebagai pengganti dari adanya proxy war karena berkedudukan di pusat pemerintahan negara.

Ketiga, penulis berpandangan bahwa sumber kerentanan yang terakhir ini terjadi karena lemahnya dan tidak memadainya aturan tentang ormas yang terdapat di dalam UU No 17 Tahun 2013. ${ }^{19}$ Dalam konteks menangani ormas Radikal kelemahan tersebut juga terlihat di dalam pasal-pasal yang ada. ${ }^{20} \mathrm{Hal}$ ini dapat memberikan ruang terhadap lepasnya ormas dari jerat hukum tuntutan sanksi. Selain itu pada umumnya suatu surat peringatan tertulis diberikan secara bertahap dan prosedurnya hanya satu kali, sehingga hal ini memperlihatkan adanya

dalam Al-Zastrouw Ng, supra note $7 \mathrm{Hlm}$ 89. Sedangkan dewan pimpinan pusat HTI berada di kawasan Tebet, Jakarta Selatan. Lihat dalam "Hizbut Tahrir Indonesia - Melanjutkan Kehidupan Islam”, online: Hizbut Tahrir Indones <https://hizbut-tahrir.or.id>.

17 "26 Ormas Siap Ikut Aksi Damai 2 Desember”, online: Republika Online <http://nasional.republika.co.id/berita/nasional/umum/16/11/19/ogv2f0257-26-ormas-siap-ikutaksi-damai-2-desember>.

18 Jonkennedi Jonkennedi, "GERAKAN HIZBUT TAHRIR DAN RAELITAS POLITIK ISLAM KONTEMPORER DI INDONESIA” (2012) 6:1 KOMUNIKA, online: <http://ejournal.iainpurwokerto.ac.id/index.php/komunika/article/view/348> Hlm 6.

19 Hal ini dapat dibuktikan dengan adanya pasal yang menyebutkan bahwa pemerintah atau pemerintah daerah melakukan upaya persuasif sebelum menjatuhkan sanksi administratif kepada ormas yang melakukan pelanggaran yang disebutkan dalam bab larangan. Lihat pasal 60 ayat 2 UU No 17 tahun 2013

${ }^{20}$ Didalam pasal pasal 62 disebutkan adanya jangka waktu tiga puluh hari dalam pemberian sanksi administratif. Sedangkan di dalam pasal 63 terdapat prosedur pemberian sanksi secara bertahap yang sangat longgar dan tidak umum. Lihat selengkapnya dalam pasal 62 dan 63 UU No.17 Tahun 2013 
Fairness and Justice: Jurnal Ilmiah Ilmu Hukum

p-ISSN: 1858-0106 e-ISSN: 2502-3926

Volume 17 Nomor 1 Mei 2019, Hlm 36-56

http://jurnal.unmuhjember.ac.id/index.php/FAJ

ketidaktegasan secara prosedural yang diberikan oleh undang-undang dan menyebabkan setiap ormas Radikal sulit untuk dicabut ijinnya. ${ }^{21}$

Setelah memaparkan tiga kerentanan diatas penulis juga perlu memberikan pandangan sesuai dengan konsep pembatasan HAM. Konsep Pembatasan HAM diperlukan dalam masyarakat yang demokratis untuk menjamin keamanan nasional dan juga keselamatan publik, terutama untuk melindungi hak dan kebebasan orang lain. ${ }^{22}$ Sehingga jaminan yang diberikan oleh konstitusi hanya diperuntukkan kepada ormas yang taat pada aturan hukum sesuai yang terdapat di dalam UU No 17 Tahun 2013. Lebih jauh lagi, Internal Convenan On Civil and Political Right (ICCPR) juga mengatur ketika suatu negara tengah dalam keadaan darurat, kebebasan ini bahkan dapat saja dikurangi penikmatannya sebagai bagian dari apa yang disebut sebagai hak yang dapat ditunda pemenuhannya. ${ }^{23}$

Tidak adanya ketegasan pemerintah dalam menindak ormas Radikal akan sangat membahayakan Kedaulatan NKRI suatu saat nanti terutama dapat dimanfaatkan pihak asing sebagai actor non-state yang menggantikan kepentingan pihak asing untuk melancarkan proxy war di Indonesia.

21 Lihat Pasal 60 sd 82 UU No 17 Tahun 2013

22 Konsep pembatasan HAM tersebut juga merupakan konsep yang diamanatkan di dalam UUD NRI 1945 Pasal 28 J serta Pasal 70 dan 73 UU No 39 Tahun 1999 Tentang HAM. Serta lihat juga selengkapnya dalam Manunggal $\mathrm{K}$ Wardaya, Konstitusionalisme dalam dinamika negara hukum (Bandar Lampung: Indepth Publishing, 2014) Hlm 53.

23 Dalam article 4 ICCPR juga disebutkan bahwa "in time of public emergency which threatens the life of the nation and the existence of which is officially proclaimed" dimana hal ini mengartikan bahwa ancaman terhadap masa depan kehidupan bangsa Indonesia dan keberadaan NKRI harus dianggap sesuatu yang genting dan memaksa sehingga pemerintah harus segera melakukan tindakan untuk melindungi segenap bangsa Indonesia dari adanya ancaman yang akan berdampak pada kedaulatan negara. Penilaian mengenai ancaman terhadap NKRI tersebut juga dikuatkan dalam pasal 22 ayat (1) UUD NRI 1945. Lihat juga selengkapnya pendapat serupa yang disampaikan oleh Manunggal K. Wardaya dalam Ibid. 
Fairness and Justice: Jurnal Ilmiah Ilmu Hukum

p-ISSN: 1858-0106 e-ISSN: 2502-3926

Volume 17 Nomor 1 Mei 2019, Hlm 36-56

http://jurnal.unmuhjember.ac.id/index.php/FAJ

\subsubsection{Penyebaran Informasi Provokatif sebagai Bentuk Alat}

\section{Melancarkan Proxy War}

Memasuki era-globalisasi yang ditandai dengan percepatan ilmu pengetahuan dan tehnologi, saat ini paradigma perang telah bergeser sehingga memiliki kekuatan besar untuk menguasai wilayah suatu negara tertentu bukan jaminan untuk memenangkan perang. Sederhananya banyak negara yang ingin memenangkan perang dengan cara pembentukan opini agar masyarakat mengikuti kehendak pihak lawan dengan sendirinya. ${ }^{24}$ Bentuk proxy war dengan cara pembentukan opini menyebarkan berita provokatif dan berita bohong (hoax) menjadi media efektif untuk menyerang akal sehat (the mind) masyarakat pada suatu negara. ${ }^{25}$

Penulis yakin bahwa dari adanya pembentukan opini dalam penyebaran berita provokatif dan juga berita hoax dapat dikategorikan sebagai bentuk propaganda yang menjadi cara terbaik untuk melancarkan proxy war khususya di Indonesia. Jika kita menarik dalam konteks kasus penyebaran informasi provokatif yang terjadi di Indonesia, hal ini juga dapat diartikan sebagai adanya suatu perlakuan yang sistematis oleh pihak asing. Beberapa kasus yang terjadi di Indonesia akhir-akhir ini yang dapat dikategorikan sebagai penyebaran berita provokatif serta hoax yaitu mengenai bangkitnya Partai Komunis Indonesia (PKI) ke tanah air. ${ }^{26}$ Keadaan tersebut semakin diperparah dengan adanya kelompokkelompok yang dengan mudah memanfaatkan media yang ada untuk menyebarkan berita provokatif dan hoax dimana imbasnya dapat

24 Susanto Zuhdi, "Proxy War Dalam Perspektif Sejarah Indonesia" dalam Riris K.Toha Sarumpaet "Krisis Budaya Oasis Guru Besar Fakultas Ilmu Pengetahuan Budaya UI", 2, 1st ed (Jakarta: Yayasan Pustaka Obor Indonesia, 2016) Hlm 280.

$25 \quad$ Ibid Hlm 281.

26 Lihat selengkapnya dalam "Bantah Keberadaan PKI, Luhut: Jangan Terpengaruh Hoax", online: <http://www.jawapos.com/read/2017/02/05/107447/bantah-keberadaan-pki-luhut-janganterpengaruh-hoax $>$. 
Fairness and Justice: Jurnal Ilmiah Ilmu Hukum

p-ISSN: 1858-0106 e-ISSN: 2502-3926

Volume 17 Nomor 1 Mei 2019, Hlm 36-56

http://jurnal.unmuhjember.ac.id/index.php/FAJ

membentuk opini yang negatif di tengah masyarakat Indonesia yang majemuk. ${ }^{27}$

Untuk lebih memastikan sejauh mana peran pihak asing dalam propaganda melalui media massa dan media sosial yang digunakan sebagai alat untuk memecah belah persatuan bangsa, Terence Qualter mengartikan propaganda sebagai suatu upaya yang disengaja oleh beberapa individu atau kelompok untuk membentuk, mengendalikan, mengubah komunikasi, membentuk opini dengan maksud agar dalam suatu keadaan tertentu mindset atau pola pikir yang mereka gunakan adalah merupakan pengaruh dari individu atau kelompok yang menyebarkan propaganda. ${ }^{28}$ Dalam konsep propaganda ini Penyebaran berita provakatif dan berita hoax dapat dikategorikan sebagai salah satu propaganda yang rentan dilakukan pihak asing. ${ }^{29}$

Selain media sosial ada juga media massa yang dalam perkembangannya menjadi salah satu media modern yang juga dapat mendukung praktek propaganda dan disinformasi. ${ }^{30}$ Jika dikaji dengan merujuk pada Undang-Undang Nomor 40 Tahun 1999 Tentang Pers (UU No 40 Tahun 1999), maka akan ditemukan kelemahan yang ada di dalam undang-undang tersebut sehingga peran media massa rentan sekali digunakan pihak asing dalam melancarkan propaganda demi kepentingan proxy war di Indonesia.

Jika melihat pada fungsi pers nasional yang terdapat di dalam UU No 40 Tahun 1999, dimana pers nasional juga berfungsi sebagai lembaga

27 "Penyebar Berita Hoax di Indonesia Bisa Raup Rp700 Jutaan", online: CNN Indones <http://www.cnnindonesia.com/teknologi/20161202085641-185-176767/penyebar-berita-hoax-diindonesia-bisa-raup-rp700-jutaan/>.

28 Asilah Amalia, "Analisis Propaganda CNN (Cable News Network) Terhadap Masyarakat Amerika Serikat Tentang Al-Qaeda" (2015), Hlm 523.

29 Ibid.

30 Adi Sulistyo, Ancaman Propaganda Media Massa Terhadap Sistem Pertahanan Negara: Kajian Pada Fungsi Pertahanan Nirmiliter (Jakarta: Asymmetric Warfare Study Program, Faculty of Defense Strategy Indonesia Defense University) Hlm 1. 
Fairness and Justice: Jurnal Ilmiah Ilmu Hukum

p-ISSN: 1858-0106 e-ISSN: 2502-3926

Volume 17 Nomor 1 Mei 2019, Hlm 36-56

http://jurnal.unmuhjember.ac.id/index.php/FAJ

ekonomi. ${ }^{31}$ Mc Chesney dalam penelitianya menjelaskan bahwa adanya propaganda berita provokatif yang dilakukan oleh pers baik dengan sengaja atau tanpa disengaja sangat dimungkinkan terjadi. ${ }^{32}$ Merujuk pada pendapat Chesney penulis juga sependapat bahwa jika melihat pada aturan yang membebaskan pers nasional berfungsi sebagai lembaga ekonomi juga akan menyebabkan kerentanan terhadap Pertahanan dan Keamanan Nasional. Selain itu menurut Fiska Maulidan Nugroho, sudah merupakan rahasia umum bahwa nyawa dari media massa salah satunya adalah iklan, sehingga kecenderungan berbasis bisnis juga menjadi sumber kerentanan yang harus ditempatkan secara seimbang dalam bingkai NKRI. ${ }^{33}$

Setelah mengkaji konsep propaganda dan peraturan perundangundangan terkait yaitu UU No 40 Tahun 1999 maka dapat diketahui bahwa media massa serta media sosial memiliki hubungan erat dengan proses propaganda untuk membentuk opini publik. Tetapi, pada dasarnya media massa hanya menjalankan perintah undang-undang dan hanya sebatas menyampaikan informasi sesuai dengan kewenangannya. Maka dari itu Pemerintah harus bertindak tegas apabila diketahui ada media massa yang melakukan kegiatan penyebaran berita provokatif yang sudah tidak sesuai dengan kewenangannya.

31 Lihat pasal 3 UU No 40 Tahun 1999

32 Lihat selengkapnya pendapat Robert Mc Chensey dalam Agus Ngadino, "Pergeseran Relasi Negara dan Media Massa dalam Kerangka Demokrasi” (2010) 42 Simbur Cahaya 1929 Hlm 4.

33 Fiska Maulidian Nugroho, "Pancasila: Refleksi Sadar Ideologi Sebagai Anti-Virus Radikalisme" dalam Al Khanif "Pancasila Dalam Pusaran Globalisasi”, 1st ed (Yogyakarta: LKis, 2017) 440 Hlm 66 
Fairness and Justice: Jurnal Ilmiah Ilmu Hukum

p-ISSN: 1858-0106 e-ISSN: 2502-3926

Volume 17 Nomor 1 Mei 2019, Hlm 36-56

http://jurnal.unmuhjember.ac.id/index.php/FAJ

\subsection{Konsep Perlindungan Hukum Kedaulatan Negara Terhadap Ancaman Proxy War}

\subsubsection{Formulasi Peraturan Perundang-Undangan Antisipasi Ancaman Nirmiliter}

Berakhirnya perang dingin menandai sejumlah perubahan penting dalam hubungan antar negara yang juga mengarah pada runtuhnya ancaman militer bagi umat manusia dan menjadikan ancaman terhadap pertahanan dan keamanan semakin kompleks karena juga melibatkan ancaman nirmiliter seperti proxy war. ${ }^{34}$ Menurut Thomas Hobbes, negara memang perlu diancam karena jika ancaman tersebut tidak ada maka bagian dari fungsi dasar negara yang mencakup pertahanan dan keamanan nasional akan hilang. ${ }^{35}$

Ancaman proxy war ini dapat diibaratkan seperti senjata kimia yang ditembakkan dimana tidak seorangpun merasakannya, tetapi tiba-tiba beberapa saat kemudian telah banyak jatuh korban. ${ }^{36}$ Untuk mencegah dan mengatasi segala bentuk ancaman proxy war yang dapat menimbulkan gangguan terhadap pertahanan dan keamanan dalam negeri maupun ancaman terhadap kedaulatan NKRI, pemerintah seharusnya membuat suatu kebijakan yang jelas dan tegas untuk menangkal ancaman proxy war. ${ }^{37}$ Berbicara mengenai kebijakan, pada dasarnya proxy war yang juga merupakan ancaman nirmiliter di bidang pertahanan negara seharusnya dapat dilihat dalam UU No.3 Tahun 2002 Tentang Pertahanan Negara. Tetapi substansi pasal yang ada didalam undang-undang tersebut, ternyata tidak mengatur secara rinci mengenai

34 Athiqah Nur Alami, "Politik Luar Negeri Dan Keamanan Non-Tradisional: Perspektif Hubungan International” dalam Politik Luar Negeri dan Isu-Isu Keamanan Non-Tradisional, 2, 1st ed (Yogyakarta: Calpulis, 2016) 192 Hlm 13.

35 Lihat selengkapnya pendapat Thomas Hobbes mengenai konsep ancaman dalam T May Rudy, Studi Strategis Dalam Transformasi Sistem Internasional Pasca Perang Dingin (Bandung: Refika Aditama, 2002) Hlm 37.

36 Yehu Wangsajaya, supra note 3 Hlm 66.

37 Ibid. 
Fairness and Justice: Jurnal Ilmiah Ilmu Hukum

p-ISSN: 1858-0106 e-ISSN: 2502-3926

Volume 17 Nomor 1 Mei 2019, Hlm 36-56

http://jurnal.unmuhjember.ac.id/index.php/FAJ

pengertian pertahanan non-militer, pengertian ancaman nirmiliter, serta juga tidak diatur mengenai larangan dan sansi untuk setiap orang dalam melakukan kegiatan yang dapat membahayakan pertahanan negara dalam menghadapi ancaman-ancaman nirmiliter seperti proxy war yang juga merupakan ancaman di bidang pertahanan negara. ${ }^{38}$

Kebijakan dalam bentuk peraturan perundang-undangan untuk mengantisipasi ancaman proxy war secara konkrit belum dimiliki oleh Pemerintah Indonesia untuk saat ini. Sehingga hal ini menjadi kendala dalam upaya preventif dalam mengantisipasi ancaman proxy war ke depan. ${ }^{39}$ Tetapi jika dikaji lebih dalam, secara historis pada pemerintahan orde lama dan orde baru Indonesia memiliki beberapa undang-undang yang dapat dipakai untuk mengantisipasi adanya ancaman dari pihak asing terutama ancaman non-militer seperti proxy war. ${ }^{40}$ Tetapi undangundang tersebut disalahgunakan oleh pihak penguasa untuk menjegal lawan politiknya pada saat itu. ${ }^{41}$

Beberapa negara di Asia telah memiliki undang-undang untuk melindungi kedaulatan negaranya dari ancaman strategis pihak asing. Negara tersebut antara lain Malaysia dan Singapura dimana wilayahnya berdekatan dengan Indonesia. Malaysia dan Singapura yang merupakan negara paling dekat dengan Indonesia memiliki Internal Security Act (ISA) atau Akta Keselamatan Dalam Negeri yang disahkan pada tahun 1960

38 Lihat pasal 7 ayat (3) dan pasal 19 UU No.3 Tahun 2002

39 Yehu Wangsajaya, supra note $3 \mathrm{Hlm} 64$.

40 Undang-undang yang dimaksud dalam hal ini yaitu undang-undang undang-undang Staatsblad 1939 No.582 (De Regeling Oop De Staat Van Oorlog En Beled atau UU SOB), undang-undang darurat dan undang-undang keadaan bahaya yang berlaku pada masa orde lama, undang-undang anti subversi pada masa orde lama dan orde baru, hingga pembahasan RUU Penanggulangan Keadaan Bahaya dan yang terakhir pembahasan terhadap RUU Keamanan Nasional setelah masa reformasi. Lihat dalam Ibid Hlm 35.

41 Marwati Djoened Poesponegoro, Nugroho Notosusanto \& Proyek Inventarisasi dan Dokumentasi Sejarah Nasional (Indonesia), Sejarah Nasional Indonesia (Departemen Pendidikan dan Kebudayaan, Direktorat Sejarah dan Nilai Tradisional, Proyek Inventarisasi dan Dokumentasi Sejarah Nasional, 1993) Hlm 311. 
Fairness and Justice: Jurnal Ilmiah Ilmu Hukum

p-ISSN: 1858-0106 e-ISSN: 2502-3926

Volume 17 Nomor 1 Mei 2019, Hlm 36-56

http://jurnal.unmuhjember.ac.id/index.php/FAJ

dan 1963. ISA memang ampuh digunakan karena di dalamnya mengandung gagasan tentang preventive detention law..$^{42}$

Bangsa Indonesia harus menyadari bahwa sebagai antisipasi terhadap ancaman proxy war yang akan terjadi di Indonesia, dengan adanya ISA yang dimiliki oleh negara tetangga yaitu Malaysia dan Singapura yang sangat berdeketan secara geografis dengan Indonesia. Maka, ancaman terhadap kedaulatan NKRI terutama adanya proxy war dan masuknya ideologi-ideologi asing seperti Radikalisme akan semakin besar terjadi di Indonesia. ${ }^{43}$

Oleh karena itu jika ingin diformulasikan kembali maka Penulis menyarankan dengan menggali sejarah bangsa Indonesia, bahwa formulasi peraturan-perundang-undangan untuk mengantisipasi ancaman proxy war di Indonesia lebih baik subtansi pasalnya dimasukkan ke dalam Rancangan Undang-Undang Keamanan Nasional (RUU Kamnas) yang baru disampaikan pemerintah pada tahun 2005 lalu atau bisa juga di formulasikan ke dalam UU No.3 Tahun 2002 dan menperjelas substansi mengenai pertahanan non-militer yang ada di dalam Undangundang tersebut. ${ }^{44}$

Bangsa Indonesia tidak perlu khawatir bahwa undang-undang tersebut akan digunakan sebagai alat menghantam lawan politik seperti zaman orde lama dan juga orde baru. Kekhawatiran itu menunjukkan bahwa masyarakat Indonesia masih trauma dan alergi dengan sejarah masa lalu, terutama pada produk-produk orde lama dan juga orde baru yang dianggapnya semua produk pada masa tersebut tidak baik.

Saat ini sudah banyak produk hukum yang mengatur atau mengantisipasi adanya kekuasaan pemerintah untuk melakukan

$42 \quad$ Yehu Wangsajaya, supra note 3 Hlm 76.

43 Ibid Hlm 43.

44 Kiki Syahnakri, "Pentingnya Undang-Undang Keamanan Nasional", Bul PPAD No IOThVIII (2012) HIm 31. 
Fairness and Justice: Jurnal Ilmiah Ilmu Hukum

p-ISSN: 1858-0106 e-ISSN: 2502-3926

Volume 17 Nomor 1 Mei 2019, Hlm 36-56

http://jurnal.unmuhjember.ac.id/index.php/FAJ

tindakan-tindakan yang represif dan juga otoriter bahkan konstitusi juga sudah mengantisipasinya. Seiring dengan berkembangnya sistem hukum di Indonesia, saat ini Indonesia menggunakan Undang-Undang Nomor 12 Tahun 2011 tentang Pembentukan Peraturan-Per-undang-undangan (UU No.12 Tahun 2011) sebagai acuan pembentukan produk hukum di Indonesia. Dalam undang-undang tersebut mengamanatkan setiap pembentukan hukum nasional harus berdasarkan Pancasila sebagai sumber segala sumber hukum negara dan juga dibuat demi kepentingan nasional. 45

Sesuai dengan pemaparan diatas maka dapat disimpulkan bahwa Indonesia sangat memerlukan adanya peraturan perundang-undangan untuk mengantisipasi ancaman proxy war sehingga Indonesia memiliki undang-undang yang dapat dijadikan sebagai upaya preventif untuk mencegah dan melindungi kedaulatan negara dari adanya ancaman proxy war dan masuknya Radikalisasi yang terjadi di Indonesia pada era globalisasi saat ini. ${ }^{46}$

\subsubsection{Pembentukan Lembaga Negara Implementasi Nilai-Nilai Pancasila}

Sampai pada pembahasan terakhir pada tulisan ini akan dikaji tentang pembentukan lembaga negara untuk membantu masyarakat dalam mengimplentasikan nilai-nilai Pancasila dalam kehidupan berbangsa dan bernegara. Adanya pembentukan lembaga negara ini semata-mata hanya untuk memberikan perlindungan hukum dan membentengi masyarakat dalam menghadapi ancaman proxy war yang bersifat nirmiliter. Perlindungan hukum yang diberikan pemerintah, selain dapat dikaji melalui peraturan perundang-undangan juga dapat diberikan oleh pemerintah melalui pembentukan suatu lembaga negara

\footnotetext{
45 Lihat pasal 2 dan 3 UU No.12 Tahun 2011

46 Yehu Wangsajaya, supra note $3 \mathrm{Hlm} 83$.
} 
Fairness and Justice: Jurnal Ilmiah Ilmu Hukum

p-ISSN: 1858-0106 e-ISSN: 2502-3926

Volume 17 Nomor 1 Mei 2019, Hlm 36-56

http://jurnal.unmuhjember.ac.id/index.php/FAJ

yang dapat dijadikan sebagai wadah untuk membantu masyarakat dalam kehidupan berbangsa dan bernegara dalam rangka perwujudan kedaulatan rakyat dan juga sistem demokrasi di Indonesia. ${ }^{47}$

Dominikus Rato berpendapat bahwa saat ini Pancasila baru dipandang sebatas simbol dan belum mendalam pada arti dan makna yang sebenarnya. Pancasila sebagai sebuah ideologi Bangsa dan Negara Indonesia adalah kebutuhan setiap warga negara Indonesia untuk dipahami dan dilaksanakan secara sadar dan sepenuh hati.48 Lalu bagaimana cara untuk mewujudkan agar masyarakat Indonesia menganggap bahwa Pancasila merupakan sebuah kebutuhan untuk dipahami dan dilaksanakan secara sadar. Maka pemerintah harus membuat suatu kebijakan yang dapat dijadikan pedoman untuk dapat memperoleh hasil yang maksimal seperti membentuk suatu lembaga yang dapat membantu bangsa Indonesia dalam mengimplementasikan nilainilai Pancasila. 49

Secara historis Indonesia pernah memiliki suatu lembaga yang dapat membantu masyarakat dalam mengimplementasikan nilai-nilai Pancasila dalam kehidupan berbangsa dan bernegara yang bernama Badan Pembinaan Pendidikan Pelaksanaan Pedoman Penghayatan dan Pengamalan Pancasila (BP.7) yang disahkan melalui Kepres Nomor 10 Tahun 1979. Pada masa orde baru, setelah SUPERSEMAR (sebelas Maret 1966), yaitu antara tahun 1966-1998 Pancasila secara normatif dimasukkan ke dalam Garis-Garis Besar Haluan Negara (GBHN) melalui TAP MPRS No.II/MPR/1978 Tentang Pedoman penghayatan dan Pengamalan Pancasila (P4). ${ }^{50}$

\footnotetext{
47 Arifin Firmansyah,dkk, Lembaga Negara dan Sengketa Kewenangan Antar Lembaga Negara, 1st ed (Jakarta: Konsorsium Reformasi Hukum Nasional dan Mahkamah Konstitusi republik Indonesia, 2005) Hlm xi.

48 Dominikus Rato, supra note $9 \mathrm{Hlm} 28$.

49 Yehu Wangsajaya, supra note $3 \mathrm{Hlm} 83$.

$50 \quad$ Dominikus Rato, supra note $9 \mathrm{Hlm} 26$.
} 
Fairness and Justice: Jurnal Ilmiah Ilmu Hukum

p-ISSN: 1858-0106 e-ISSN: 2502-3926

Volume 17 Nomor 1 Mei 2019, Hlm 36-56

http://jurnal.unmuhjember.ac.id/index.php/FAJ

Setelah berjalannya penataran $\mathrm{P} 4$, pada era reformasi terjadi desakan masyarakat akan adanya agenda reformasi yang salah satunya menuntut bahwa P4 harus dihapuskan karena menjadi alat yang digunakan oleh penguasa orde baru untuk mempertahankan kekuasaan dan menghantam lawan politiknya yang dianggap tidak Pancasilais. ${ }^{51}$ Masyarakat yang pesimis terhadap Pancasila mendesak untuk menghapuskan P4 yang secara otomatis diikuti dengan pembubaran BP.7.52

Faktanya Setelah pencabutan terhadap P4 tersebut, perkembangan kehidupan berbangsa dan bernegara saat ini banyak yang keluar dari nilai yang ada di dalam Pancasila itu sendiri. Bahkan Mafud MD menyatakan bahwa gema Pancasila sudah sangat mengendur di era reformasi ini. ${ }^{53}$ Padahal P4 merupakan sebuah alat yang dapat dijadikan penyaring dalam masuknya ideologi-ideologi asing ke Indonesia termasuk radikalisme dan extremisme.

Memasuki era reformasi yang terus berjalan akhirnya banyak lembaga negara dan juga lembaga pemerintahan yang melakukan fungsi sosialisasi Pancasila dalam lingkup kerjanya masing-masing. ${ }^{54}$ Tetapi meskipun demikian, Bayu Dwi Anggono berpendapat bahwa dewasa ini bangsa Indonesia masih memiliki tantangan pembangunan karakter di masyarakatnya.55 Sejalan dengan pemikiran tersebut, penulis

51 Anis Ibrahim, "Perspektif Futuristik Pancasila Sebagai Asas/Ideologi dalam UU Keormasan" (2010) 3:2 J Konstitusi, online: <http://publishing-widyagama.ac.id/ejournalv2/index.php/jk/article/view/322> Hlm 130.

52 Diposkan oleh Forum Kajian Hukum dan Konstitusi, "Refleksi TAP MPR No. II/MPR/1978 Tentang Pedoman Penghayatan dan Pengamalan Pancasila (P4)", online: <http://forumkajianhukumdankonstitusi.com/2013/01/menatap-ulang-peranan-sertaefektivitas_9989.html>.

53 Ibrahim, supra note $51 \mathrm{Hlm} 129$.

54 Beberapa lembaga pemerintah yang melakukan sosialisasi Pancasila dalam lingkup kerja masing-masing yang penulis maksudkan seperti Kemendagri melalui Badan Kesatuan Bangsa Dan Politik, kementerian agama melalui FKUB, mahkamah konstitusi melalui sosialisasi Pancasila dan UUD 1945, MPR RI melalui sosiaisasi 4 Pilar Kebangsaan.

55 Bayu Dwi Anggono, "Jurnal Konstitusi: Konstitusionalitas dan Model Pendidikan Karakter Bangsa Pasca Putusan Mahkamah Konstitusi" (2014) 11 No.3 Kepaniteraan Dan Sekertariat Jenderal Mahkamah Konstitusi Republik Indonesia 244 Hlm 504. 
Fairness and Justice: Jurnal Ilmiah Ilmu Hukum

p-ISSN: 1858-0106 e-ISSN: 2502-3926

Volume 17 Nomor 1 Mei 2019, Hlm 36-56

http://jurnal.unmuhjember.ac.id/index.php/FAJ

beranggapan bahwa pembentukan lembaga negara yang dapat membantu masyarakat dalam mengimplementasikan nilai-nilai Pancasila merupakan hal yang tepat untuk dilakukan saat ini. Hal ini dapat dianggap sebagai alat bantu serta untuk mensinergikan sosialisasi mengenai Pancasila yang dilaksanakan oleh lembaga-lembaga negara dan pemerintahan sehingga nantinya dapat mengantisipasi terjadinya ancaman proxy war lebih luas lagi.

Presiden Joko Widodo telah mengeluarkan Peraturan Presiden Nomor 54 Tahun 2017 Tentang Unit Kerja Presiden Pembinaan Ideologi Pancasila (UKPPIP). Dengan adanya Perpres tersebut pada akhirnya Indonesia memiliki suatu lembaga pemerintah non-struktural yang dapat membantu masyarakat dalam mengimplementasikan nilai-nilai Pancasila dalam kehidupan berbangsa dan bernegara. ${ }^{56}$ Lembaga seperti ini merupakan penggabungan dari beberapa fungsi yang sebelumnya tersebar di beberapa lembaga untuk disatukan dalam satu lembaga khusus yang memiliki kewenangan lebih kuat dan memiliki legitimasi di tingkat nasional. ${ }^{57}$

Dengan semakin merebaknya paham Radikalisasi di Indonesia sebagaimana yang telah dijelaskan dalam pembahasan sebelumnya, dengan adanya pemantapan Ideologi Pancasila yang dikoordinasikan oleh UKP-PIP nantinya dapat meredam penyebaran paham Radikal terutama juga untuk menjaring ormas-ormas yang bertentangan dengan Pancasila atau menolak Pancasila sebagai ideologi tunggal di Indonesia sebagaimana telah diatur dalam UU No.17 Tahun 2013. Dengan adanya penyebaran Radikalisasi dan adanya kelompok-kelompok yang ingin menggantikan Ideologi Pancasila dengan ideologi lain sejatinya dapat membahayakan kedaulatan NKRI khususnya untuk dimanfaatkan pihak asing dalam melancarkan proxy war.

\footnotetext{
56 "Jokowi wacanakan bentuk badan khusus pemantapan Pancasila", online: merdeka.com $<$ https://www.merdeka.com/peristiwa/jokowi-wacanakan-bentuk-badan-khusus-pemantapanpancasila.html>.

57 Bayu Dwi. supra note $55 \mathrm{Hlm} 511$.
} 
Fairness and Justice: Jurnal Ilmiah Ilmu Hukum

p-ISSN: 1858-0106 e-ISSN: 2502-3926

Volume 17 Nomor 1 Mei 2019, Hlm 36-56

http://jurnal.unmuhjember.ac.id/index.php/FAJ

Penulis sangat yakin dengan adanya lembaga pemantapan nilai-nilai Pancasila seperti UKP-PIP akan sangat membantu Bangsa Indonesia untuk siap menghadapi segala ancaman seperti proxy war jika bangsa Indonesia mau bersatu dan saling bahu-membahu mendukung satu sama lain dalam kehidupan berbangsa dan bernegara.

\section{Kesimpulan}

Berdasarkan uraian pembahasan yang telah disampaikan di dalam bab sebelumnya pada artikel ini, dapat ditarik beberapa kesimpulan. Beberapa kesimpulan tersebut yakni sebagai berikut:

1. Ormas Radikal rentan untuk dimanfaatkan oleh pihak asing sebagai actor non-state dalam proxy war. Kerentanan tersebut dapat dibuktikan, pertama dari adanya paham Radikal yang dianut bahkan sangat membahayakan eksistensi Ideologi Pancasila, kedua letak keberadaan ormas Radikal yang berkedudukan di pusat pemerintahan negara, ketiga adanya UU No 17 Tahun 2013 yang kurang memadai.

2. Penyebaran informasi provokatif melalui media massa dan media sosial dapat disimpulkan memiliki hubungan dengan adanya propaganda yang rentan digunakan pihak asing sebagai alat untuk melancarkan proxy war di Indonesia, Meskipun belum dapat dibuktikan ikut berperan secara langsung dalam proses propaganda.

3. Kebijakan dalam bentuk peraturan perundang-undangan untuk mengantisipasi ancaman nirmiliter seperti proxy war secara konkrit belum dimiliki oleh Indonesia untuk saat ini, sehingga menjadi kendala dalam upaya preventif antisipasi ancaman proxy war.

4. Saat ini Pancasila baru dipandang sebatas simbol sehingga, bangsa Indonesia sangat memerlukan lembaga pemantapan nilai-nilai pancasila seperti UKP-PIP yang baru dibentuk sebagai upaya untuk siap menghadapi segala bentuk ancaman nirmiliter seperti proxy war. 
Fairness and Justice: Jurnal Ilmiah Ilmu Hukum

p-ISSN: 1858-0106 e-ISSN: 2502-3926

Volume 17 Nomor 1 Mei 2019, HIm 36-56

http://jurnal.unmuhjember.ac.id/index.php/FAJ

\section{Daftar Pustaka}

\section{$\underline{\text { Buku }}$}

Alami Athiqah Nur. (2016). Politik Luar Negeri Dan Isu-Isu Keamanan Non-

Tradisional, 1st ed. Yogyakarta: Calpulis

Al Khanif. (2016). Pancasila Sebagai Realitas Percik Pemikiran Tentang

Pancasila Isu-Isu Kontemporer Indonesia, 1st ed. Yogyakarta: Pustaka

Pelajar.

- - - . (2017). Pancasila Dalam Pusaran Globalisasi, 1st ed. Yogyakarta: LKis

Firmansyah Arifin,dkk. (2005). Lembaga Negara dan Sengketa Kewenangan

Antar Lembaga Negara, 1st ed. Jakarta: Konsorsium Reformasi

Hukum Nasional dan Mahkamah Konstitusi republik Indonesia

Ng Al-Zastrouw. (2005). Gerakan Islam Simbolik: Politik Kepentingan FPI, 1st

ed. Yogyakarta: LKIS Pelangi Aksara

Poesponegoro, Marwati Djoened, Nugroho Notosusanto \& Proyek

Inventarisasi dan Dokumentasi Sejarah Nasional (Indonesia).

(1993). Sejarah Nasional Indonesia. Departemen Pendidikan dan

Kebudayaan, Direktorat Sejarah dan Nilai Tradisional, Proyek

Inventarisasi dan Dokumentasi Sejarah Nasional

Rudy T.May. (2002). Studi Strategis Dalam Transformasi Sistem Internasional

Pasca Perang Dingin. Bandung: Refika Aditama, 2002

Sarumpaet Riris K.Toha. (2016). Krisis Budaya Oasis Guru Besar Fak Ilmu

Pengetahuan Budaya UI, 2, 1st ed. Jakarta: Yayasan Pustaka Obor Indonesia

Wahid Abdurrachman. (2009). Ilusi Negara Islam: Ekspansi Gerakan Islam

Transnasional di Indonesia, 1st ed. Jakarta:The Wahid Institute

Wangsajaya Yehu. (2016). Meningkatkan Kewaspadaan Nasional Terhadap

Proxy War, 1. Jakarta: RajaGrafindo Persada 
Fairness and Justice: Jurnal Ilmiah Ilmu Hukum

p-ISSN: 1858-0106 e-ISSN: 2502-3926

Volume 17 Nomor 1 Mei 2019, Hlm 36-56

http://jurnal.unmuhjember.ac.id/index.php/FAJ

Wardaya Manunggal K. (2014). Konstitusionalisme dalam dinamika negara hukum. Bandar Lampung: Indepth Publishing

\section{Jurnal}

Amalia, Asilah. (2015). "Analisis Propaganda CNN (Cable News Network) Terhadap Masyarakat Amerika Serikat Tentang Al-Qaeda", online: $\quad$ <http://ejournal.hi.fisip-unmul.ac.id/site/wpcontent/uploads/2015/08/1138.-Asilah-Amalia-1102045038.pdf>.

Bayu Dwi Anggono. (2014). "Jurnal Konstitusi: Konstitusionalitas dan Model Pendidikan Karakter Bangsa Pasca Putusan Mahkamah Konstitusi" (2014) 11 No.3 Kepaniteraan Dan Sekertariat Jenderal Mahkamah Konstitusi Repub Indones 244.

Damayanti, Ninin Prima. (2012). et al. "Radikalisme Agama Sebagai Salah satu Bentuk Perilaku Menyimpang : Studi Kasus Front Pembela Islam" (2012) 3:1 J Kriminol Indones, online: <http://journal.ui.ac.id/jki/article/view/1119>.

Ibrahim, Anis. (2010). "Perspektif Futuristik Pancasila Sebagai Asas/Ideologi dalam UU Keormasan" (2010) 3:2 J Konstitusi, online: $<$ http://publishing-widyagama.ac.id/ejournalv2/index.php/jk/article/view/322>.

Jonkennedi, Jonkennedi. (2012). “GERAKAN HIZBUT TAHRIR DAN RAELITAS POLITIK ISLAM KONTEMPORER DI INDONESIA" (2012) $6: 1$ KOMUNIKA, online: $<$ http://ejournal.iainpurwokerto.ac.id/index.php/komunika/article/ view/348>

Kiki Syahnakri. (2012).“Pentingnya Undang-Undang Keamanan Nasional", Bul PPAD No 10ThVIII . 
Fairness and Justice: Jurnal Ilmiah Ilmu Hukum

p-ISSN: 1858-0106 e-ISSN: 2502-3926

Volume 17 Nomor 1 Mei 2019, Hlm 36-56

http://jurnal.unmuhjember.ac.id/index.php/FAJ

Sidi Alkahfi Setiawan. (2013). Perlindungan Hukum Pekerja Pemegang Saham Di PT Bank Central Asia Tbk. Fakultas Hukum Universitas Jember. Jember.

Wildan, Dadan, M Hum \& Staf Khusus Menteri Sekretaris Negara RI. (2014).“Membuka Catatan Sejarah: Detik-Detik Proklamasi, 17 Agustus 1945" (2014) 17 Minist State Secr Repub Indones Jkt, online: http://server2.docfoc.com/uploads/Z2015/11/29/OKdbnIgKUY/de 9fc69deb93ee287d1f04fa401fd52b.doc

\section{Tesis atau Disertasi}

Sulistyo Adi. (2015) Ancaman Propaganda Media Massa Terhadap Sistem Pertahanan Negara: Kajian Pada Fungsi Pertahanan Nirmiliter (Jakarta: Asymmetric Warfare Study Program, Faculty of Defense Strategy Indonesia Defense University).

\section{Website Resmi}

Forum Kajian Hukum dan Konstitusi. "Refleksi TAP MPR No. II/MPR/1978 Tentang Pedoman Penghayatan dan Pengamalan Pancasila (P4)", online: <http:// forumkajianhukumdankonstitusi.com/2013/01/menatapulang-peranan-serta-efektivitas_9989.html>.

"Jokowi wacanakan bentuk badan khusus pemantapan Pancasila", online: merdeka.com <https://www.merdeka.com/peristiwa/jokowi-wacanakanbentuk-badan-khusus-pemantapan-pancasila.html>.

"Arti kata rentan - Kamus Besar Bahasa Indonesia (KBBI) Online", online: $<$ http://kbbi.web.id/rentan>.

"Hizbut Tahrir Indonesia - Melanjutkan Kehidupan Islam", online: Hizbut Tahrir Indones < https:/ / hizbut-tahrir.or.id>. 
Fairness and Justice: Jurnal Ilmiah Ilmu Hukum

p-ISSN: 1858-0106 e-ISSN: 2502-3926

Volume 17 Nomor 1 Mei 2019, Hlm 36-56

http://jurnal.unmuhjember.ac.id/index.php/FAJ

"26 Ormas Siap Ikut Aksi Damai 2 Desember", online: Repub Online <http://nasional.republika.co.id/berita/nasional/umum/16/11/19/ ogv2f0257-26-ormas-siap-ikut-aksi-damai-2-desember> .

"Bantah Keberadaan PKI, Luhut: Jangan Terpengaruh Hoax", online: <http://www.jawapos.com/read/2017/02/05/107447/bantahkeberadaan-pki-luhut-jangan-terpengaruh-hoax>.

"Penyebar Berita Hoax di Indonesia Bisa Raup Rp700 Jutaan", online: CNN Indones <http://www.cnnindonesia.com/teknologi/20161202085641-185176767/ penyebar-berita-hoax-di-indonesia-bisa-raup-rp700-jutaan/>. 